\title{
Hyponatremia prolongs hospital stay in patients with community-acquired pneumonia
}

\author{
Shinichiro OKAUCHi ${ }^{1}$ (ID) \\ Hiroaki SATOH $^{1}$ (ID)
}

\author{
${ }^{1}$ Division of Respiratory Medicine, Mito Medical Center, Tsukuba University, \\ Mito, Japan \\ ${ }^{1}$ Tsukuba Üniversitesi Mito Tıp Merkezi, Göğüs Hastalıkları Bölümü, \\ Mito, Japonya
}

Cite this article as: Okauchi S, Satoh H. Hyponatremia prolongs hospital stay in patients with communityacquired pneumonia. Tuberk Toraks 2020;68(2):198199.

\section{Yazışma Adresi (Address for Correspondence)}

\section{Dr. Hiroaki SATOH}

Division of Respiratory Medicine, Mito Medical Center, Tsukuba University, Miya-machi 3-2-7,

Ibaraki, 310-0015, MITO - JAPAN

e-mail: hirosato@md.tsukuba.ac.jp

CCopyright 2020 by Tuberculosis and Thorax.

Available on-line at www.tuberktoraks.org.com
Dear Editor,

We read with interest the article entitled "Hyponatremia prolongs hospital stay and hypernatremia better predicts mortality than hyponatremia in hospitalized patients with community-acquired pneumonia" by Tokgöz Akyıl F, et al. (Tuberk Toraks 2019;67:239-247) (1). We were particularly interested in hyponatremia and prolonged hospital stay in patients with community-acquired pneumonia, so we would like to discuss four issues. First, please let us know when the baseline sodium levels in this study were measured, for example, at first visit, at the time of hospitalization, or at the time of initiation of antibiotics. We would like to know whether we should evaluate a single measurement or multiple measurements of serum sodium in this type of research. Second, the authors described that the kidney and thirst center of the hypothalamus play the major role in sodium regulation (1). In addition to this, the authors also indicated malignancies and infections as causes of hyponatremia. How was hyponatremia related to poor oral intake and nutritional status? As shown in Table 1, patients with hyponatremia also have low serum levels of albumin (1). Taking these information into consideration, was there a relationship between poor oral intake and hyponatremia? Third, the authors described that the most frequent co-morbidities to hyponatremia were chronic obstructive pulmonary disease or asthma (1). What was the relationship between hyponatremia and these diseases? There are many patients with COPD with low body mass index (BMI) and who have flail or sar- 
copenia $(2,3)$. Were there associations with low BMI, malnutrition or sarcopenia in patients with COPD? Also, the authors wrote that there were 79 patients with congestive heart failure (1). Please let us know whether there was any relationship between hyponatremia and diuretics in these patients. Fourth, in the conclusion part, the authors state that appropriate treatment should be given in dysnatremia with closer medical examination. We do appreciate letting us know whether dysnatremia easily improved with appropriate treatment.

\section{REFERENCES}

1. Tokgöz Akyıl F, Akyıl M, Çoban A ğca M, Güngör A, Ozantürk E, Sögüt G, et al. Hyponatremia prolongs hospital stay and hypernatremia better predicts mortality than hyponatremia in hospitalized patients with community-acquired pneumonia. Tuberk Toraks 2019;67(4):239-47.

2. Raad S, Smith C, Allen K. Nutrition status and chronic obstructive pulmonary disease: can we move beyond the body mass index? Nutr Clin Pract 2019;34(3):330-9.

3. Collins PF, Yang IA, Chang YC, Vaughan A. Nutritional support in chronic obstructive pulmonary disease (COPD): an evidence update. J Thorac Dis 2019;11(Suppl 17):S2230-S7 